\title{
Pemahaman Konsep Hospitality Pada Pelaku Pariwisata di Kabupaten Berau
}

\author{
Theodosia C. Nathalia ${ }^{1}$ dan Yustisia Kristiana ${ }^{2}$ \\ Fakultas Pariwisata Universitas Pelita Harapan \\ E-mail : theodosia.nathalia@uph.edu'1, yustisia.kristiana@uph.edu²
}

\begin{abstract}
As a tourist destination, Berau Regency has experienced a significant increase in tourist visits in recent years. Tourism development in Berau Regency still faces several obstacles, including the low quality of tourism destination management, not yet optimal management of regional culture and promotion of tourism destinations that have not been optimal. The tourism industry is closely associated with hospitality which is a major advantage of other industries. There is a need to explore the perceptions of tourism stakeholders about the hospitality concept. The purpose of this study is to analyze the level of understanding of hospitality concepts in tourism stakeholders in Berau Regency. Determination of respondents was done through purposive sampling and snowball sampling methods. Respondents were chosen with the consideration concerned having experience and knowledge in accordance with the focus of the study. The collected data was analyzed by descriptive narrative results of interviews with speakers and results of observations. The results of the study show that tourism stakeholders understand the service more than hospitality concept. Most of tourism stakeholders cannot accurately describe hospitality or distinguish it from service. Only a few of tourism stakeholders can define and describe the hospitality concept, but this still refers to service management terms and concepts. Most tourism stakeholders struggle to express their understanding and perception of hospitality. Practices consistently in carrying out the concept of hospitality can influence the behavior of tourism stakeholders.
\end{abstract}

Keywords: hospitality, tourism stakeholders, Berau

\begin{abstract}
Abstrak: Sebagai destinasi wisata, Kabupaten Berau mengalami kenaikan kunjungan wisatawan yang cukup mengesankan pada beberapa tahun terakhir. Pengembangan pariwisata di Kabupaten Berau masih menemui beberapa kendala, antara lain masih rendahnya kualitas pengelolaan destinasi wisata, belum optimalnya pengelolaan budaya daerah dan promosi destinasi pariwisata yang belum optimal. Industri pariwisata lekat dengan keramahtamahan atau hospitality yang merupakan keunggulan utama dari industri lainnya. Sehingga terdapat kebutuhan untuk mengeksplorasi persepsi pelaku pariwisata tentang konsep hospitality. Tujuan dari penelitian ini adalah untuk menganalisis tingkat pemahaman konsep hospitality pada pelaku pariwisata di Kabupaten Berau. Penentuan responden dilakukan melalui metode purposive sampling dan snowball sampling. Responden dipilih dengan pertimbangan yang bersangkutan memiliki pengalaman dan pengetahuan sesuai dengan fokus penelitian. Data yang terkumpul dianalisis dengan cara deskriptif naratif hasil wawancara dengan narasumber dan hasil observasi. Hasil dari penelitian menunjukkan bahwa pelaku pariwisata lebih memahami konsep layanan daripada hospitality. Mayoritas pelaku pariwisata tidak dapat secara akurat menggambarkan hospitality atau membedakannya dari layanan. Hanya sedikit dari pelaku pariwisata yang mampu mendefinisikan dan menggambarkan konsep hospitality, namun ini pun masih mengacu pada istilah dan konsep manajemen layanan. Sebagian besar pelaku pariwisata berjuang untuk mengungkapkan pemahaman dan persepsi tentang hospitality. Praktik yang konsisten dalam menjalankan konsep hospitality dapat memengaruhi perilaku dari pelaku pariwisata.
\end{abstract}

Kata kunci: hospitality, pelaku pariwisata, Berau

\subsection{Latar Belakang}

Sektor pariwisata telah menjadi sektor andalan Indonesia. Hal ini ditunjukkan dengan angka pertumbuhan jumlah kunjungan wisatawan. Untuk kunjungan wisatawan mancanegara, bila dilihat sejak 2014 terdapat kenaikan yang cukup signifikan. Pada 2014 sebesar 9,3 juta, kemudian pada 2015 naik menjadi 10,4 juta, lalu pada 2016 menembus 12 juta, dan tahun 2017 mencapai 13,7 juta. Jumlah wisatawan nusantara (wisnus) juga mengalami kenaikan. Pada tahun 2017 sebanyak 277 juta pergerakan dari proyeksi 265 juta wisatawan. Sedangkan pada 2016, dari proyeksi 260 juta terlampaui hingga 264 juta. Kemudian pada 2015 juga melebihi target dari 255 juta, tercapai 256 juta. Penerimaan PDB dan devisa dari sektor pariwisata pada tahun 2017 adalah sebesar 5 persen dan Rp. 200 triliun serta penyerapan tenaga kerja pariwisata sebanyak 13 juta orang. Angka pertumbuhan ini merupakan hasil pengembangan beragam jenis wisata serta komponen pendukung lainnya untuk menarik ISSN : 2087-0086 (print), 2655-5433 (online) 
wisatawan berkunjung ke Indonesia (Kementerian Pariwisata Republik Indonesia, 2017).

Jenis wisata yang menjadi unggulan di Indonesia adalah wisata alam, khususnya wisata bahari. Pulau Bali selama ini menjadi objek wisata bahari yang sangat populer. Namun, dengan berkembangnya pembangunan infrastruktur dan teknologi informasi, objek wisata bahari lainnya yang sangat berpotensi besar untuk dikembangkan. Salah satu destinasi yang terus mengembangkan daya tarik wisata bahari adalah Kabupaten Berau. Kabupaten Berau memiliki Kepulauan Derawan. Kepulauan ini terdiri dari gabungan beberapa pulau pulau kecil yaitu Pulau Derawan, Pulau Maratua, Pulau Kakaban, dan Pulau Sangalaki. Kepulauan Derawan adalah bagian dari ekoregion laut Sulu-Sulawesi yang melintasi Indonesia, Malaysia, dan Filipina. Ekoregion ini terletak di pusat kawasan segitiga karang dunia dengan keanekaragaman hayati karang tertinggi di dunia. Segitiga karang dunia ini disebut juga the coral triangle, karena menjadi episenter kehidupan laut yang memiliki keragaman biota laut. Terumbu karang di kawasan ini mencakup 53\% terumbu karang dunia. Bahkan berdasarkan penelitian yang dikembangkan, Kepulauan Derawan merupakan salah satu multi countries feeding ground yang terpenting di dunia (Dinas Kebudayaan dan Pariwisata Kabupaten Berau, 2016).

Sebagai destinasi wisata, Kabupaten Berau mengalami kenaikan kunjungan wisatawan yang cukup mengesankan pada beberapa tahun terakhir.

Tabel 1. Jumlah Kunjungan Wisatawan ke Kabupaten Berau

\begin{tabular}{|c|c|c|c|}
\hline Tahun & Wisnus & Wisman & Total \\
\hline 2012 & 66.024 & 837 & 66.861 \\
\hline 2013 & 80.753 & 4.026 & 84.779 \\
\hline 2014 & 77.574 & 10.728 & 88.302 \\
\hline 2015 & 99.416 & 6.119 & 105.535 \\
\hline 2016 & 130.023 & 2.573 & 132.596 \\
\hline
\end{tabular}

Sumber: (BPS Kabupaten Berau, 2017)

Berdasarkan data di atas menunjukkan bahwa sektor pariwisata mulai menjadi sektor andalan bagi Kabupaten Berau. Hanya saja pengembangan pariwisata masih menemui beberapa kendala. Permasalahan pembangunan pariwisata di Kabupaten Berau antara lain adalah masih rendahnya kualitas pengelolaan destinasi wisata, belum optimalnya pengelolaan budaya daerah dan promosi destinasi pariwisata yang belum optimal. Untuk permasalahan kualitas pengelolaan destinasi wisata, dilatarbelakangi oleh kualitas dan kuantitas SDM yang masih terbatas dan kondisi sarana prasarana pendukung daya tarik wisata yang belum memadai (Gazali, 2017).

Permasalahan SDM pariwisata perlu mendapatkan perhatian, karena hal ini akan memengaruhi persepsi dan tingkat kepuasan wisatawan terhadap Kabupaten Berau. Kepuasan adalah perasaan puas atau kecewa seseorang yang dihasilkan dari perbandingan performa produk atau hasil dengan ekspektasi. Jika performanya kurang dari ekspektasi maka konsumen akan kecewa dan jika sesuai dengan ekspektasi konsumen akan merasa puas diartikan sebagai upaya pemenuhan sesuatu atau membuat sesuatu memadai (Kotler \& Keller, 2015). Kepuasan wisatawan diawali dari saat kedatangan, selama melakukan aktivitas di destinasi hingga kembali ke tempat asalnya. Industri pariwisata lekat dengan keramahtamahan atau hospitality yang merupakan keunggulan utama dari industri lainnya dengan cara memperlakukan pelanggan dengan kehangatan, kebaikan dan perhatian yang tulus, selain proses manajemen layanan yang efektif. Sifat dari bisnis pariwisata yang melibatkan baik layanan yang berwujud dan tidak berwujud, istilah yang biasa digunakan dalam literatur untuk konteks manajemen adalah manajemen jasa (Kandampully \& Solnet, 2015). Ini merupakan teoritis rerangka kerja dalam manajemen pariwisata, yang memiliki kecenderungan untuk menekankan prinsip-prinsip hospitality. Dengan demikian, nomenklatur tuan rumah (host), tamu (guest), hubungan antara tuan rumah dengan tamu, dapat digantikan dengan istilah-istilah seperti penyedia layanan atau karyawan, pelanggan atau klien, interaksi pelanggan dengan karyawan (service encounter), nilai uang (value for money) dan motif tersembunyi (ulterior motive).

Saat ini pentingnya memahami fenomena hospitality telah menjadi minat baru dalam literatur akademik. Pizam (2005) menganjurkan istilah hospitality untuk membedakan sektor pariwisata dari layanan sektor lainnya. Lashley (2007) menyetujui penyataan tersebut dan menunjukkan peran hubungan antara tuan rumah dengan tamu dan tanggung jawab sosial dan budaya yang terkait dengan kedua peran tersebut. Begitu pula Teng (2011) yang menyatakan bahwa perusahaan mendapatkan keuntungan melalui pendekatan hubungan timbal balik, untuk menemukan keseimbangan antara tujuan komersial yaitu profitabilitas dengan kepuasan pelanggan.

Oleh karena itu, terdapat kebutuhan yang berkembang untuk penelitian yang mengeksplorasi persepsi pelaku pariwisata, 
dan bagaimana ini dapat memengaruhi perilaku dan persepsi pelaku pariwisata terhadap praktik organisasi. Maksud dari penelitian ini adalah untuk memperoleh informasi mengenai sejauh mana pemahaman konsep hospitality para pelaku pariwisata. Tujuan dari penelitian ini adalah untuk menganalisis (mengkaji) tingkat pemahaman konsep hospitality pada pelaku pariwisata di Kabupaten Berau.

\subsection{Kajian Pustaka \\ 2.1.1. Pariwisata}

Menurut Cook, Hsu, \& Taylor (2018) pariwisata adalah perpindahan sementara yang dilakukan oleh manusia ke tujuan diluar tempat tinggalnya dan tempat bekerjanya, kegiatan yang dilakukan selama menetap di daerah tujuan, dan fasilitas diciptakan untuk memenuhi kebutuhan. Sedangkan menurut Cooper, Fletcher, Fyall, Gilbert, \& Wanhill, (2008), terdapat empat komponen utama yang harus dimiliki oleh pihak destinasi, diantaranya yaitu attractions, amenities, accesibility dan ancillary services.

Atraksi adalah segala sesuatu yang menjadi daya tarik dari sebuah daerah untuk dikunjungi. Jenis-jenis atraksi diantaranya natural attraction (atraksi alami) yaitu daya tarik wisata yang ada secara alamiah dan terbentuk karena adanya sebuah proses alam, cultural attraction yaitu atraksi budaya adalah segala atraksi yang berdasarkan pada kebudayaan dan man made attraction (atraksi buatan) yaitu atraksi buatan adalah segala atraksi yang dibuat oleh manusia.

Amenities adalah segala fasilitas yang menunjang kebutuhan wisatawan di tempat tujuan. Fasilitas penunjang ini seperti akomodasi dan restoran. Akomodasi adalah suatu usaha menggunakan suatu bangunan atau sebagian bangunan yang disediakan secara khusus, dan setiap orang dapat menginap, makan serta memperoleh pelayanan dan fasilitas lainnya dengan pembayaran. Restoran merupakan tempat yang menyediakan makanan dan minuman bagi pengunjung. Selain itu adalah retailing yaitu kegiatan penjualan produk barang dan jasa.

Accesibility adalah kemudahan wisatawan dalam mencapai destinasi wisata memengaruhi kesuksesan dari destinasi wisata tersebut. Pengembangan dan perawatan transportasi yang baik akan membuat wisatawan mudah mencapai ke destinasi wisata. Contoh dari akses yang meningkatkan kualitas pengalaman wisatawan adalah bis wisata yang berkeliling dengan pemandangan yang indah, shuttle bus yang diperuntukkan bagi wisatawan dari hotel menuju tempat wisata, dan jalanan khusus untuk bersepeda.

Menurut Holloway \& Taylor (2006), ancillary services merupakan jasa tambahan yang menyediakan pelayanan termasuk di dalamnya adalah pemandu wisata, jasa kurir, agen periklanan, konsultan, penyediaan training dan edukasi, pemasaran, dan koordinasi aktivitas. Layanan yang pada umumnya disediakan oleh organisasi lokal adalah promosi daerah tujuan wisata, koordinasi dan pengembangan, penyediaan informasi dan jasa reservasi, sarana dan koordinasi bisnis lokal serta penyediaan fasilitas yang diperlukan seperti katering dan lapangan olahraga.

\subsubsection{Hospitality}

Bidang hospitality, menurut definisi, adalah industri jasa. Tugasnya adalah menciptakan keuntungan bagi pemegang saham dengan melayani dan memuaskan tamu. Segmen industri meliputi hotel, restoran, layanan makanan dan minuman, perencanaan acara, bisnis pariwisata terkait, dan penyedia perjalanan. Pada umumnya produk yang dibeli tidak berwujud atau kualitas yang dirasakan dari produk yang dibeli dipengaruhi oleh metode layanan yang diterima. Langhorn (2004) mencatat bahwa dalam hospitality, penyedia layanan adalah "bagian dari produk itu sendiri". Agar para tamu merasa puas, tamu tidak hanya harus percaya bahwa telah menerima layanan berharga untuk uang yang telah dikeluarkan, tetapi juga merasa dihargai dan dihormati oleh para karyawan yang menyediakan layanan (Kernbach \& Schutte, 2005; Langhorn, 2004; Varca, 2004; Winsted, 2000). Dalam industri hospitality terdapat empat sektor industri, yaitu (Popova, 2012) makanan dan minuman (food \& beverage), akomodasi (lodging), rekreasi (recreation) dan perjalanan (travel).

\subsubsection{Hasil Penelitian Sebelumnya}

Hospitality dan layanan (service) samasama penting dalam bisnis pariwisata. Jadi, penting untuk memastikan penyediaan layanan yang ramah yang memfasilitasi pengalaman tamu dan memengaruhi kepuasan serta loyalitas. Sejalan dengan Pezzotti (2011) dan Meyer (2008) yang menyatakan bahwa hosptality penting di industri pariwisata dengan komponen utamanya adalah perilaku, sementara layanan merupakan sarana dalam mewujudkan hospitality. Layanan dilihat sebagai kinerja teknis, sementara hospitality lebih kepada representatif sikap dan semangat dengan layanan yang dilakukan. 


\subsection{Metode Penelitian}

Penelitian ini menggunakan metode penelitian kualitatif. Penelitian kualitatif yaitu suatu penelitian ilmiah, yang bertujuan untuk memahami suatu fenomena dalam konteks sosial secara alamiah dengan mengedepankan proses interaksi komunikasi yang mendalam antara peneliti dengan fenomena yang diteliti (Moleong, 2010). Penelitian kualitatif sebagai prosedur penelitian yang menghasilkan data deskriptif berupa kalimat tertulis atau lisan, serta gambar dari orang dan obyek wisata yang diamati. Penelitian ini merupakan penelitian deskriptif. Peneliti berupaya menggambarkan tingkat pemahaman konsep hospitality pada pelaku pariwisata di Kabupaten Berau.

Penentuan sampel (responden) dilakukan melalui metode purposive sampling dan snowball sampling. Purposive sampling merupakan teknik penentuan sampel dengan pertimbangan khusus sehingga layak dijadikan sampel (Sugiyono, 2016). Sedangkan snowball sampling adalah teknik penentuan sampel yang mula-mula jumlahnya kecil, kemudian membesar (Sugiyono, 2016). Dalam penelitian ini, responden dipilih dengan pertimbangan yang bersangkutan memiliki pengalaman dan pengetahuan sesuai dengan fokus penelitian. Data yang terkumpul dianalisis dengan cara deskriptif naratif hasil wawancara dengan narasumber dan hasil observasi. Penelitian juga akan menganalisa referensi tentang Kabupaten Berau dan data pariwisata Kabupaten Berau.

\subsection{Hasil dan Pembahasan}

\subsubsection{Hasil}

Kabupaten Berau memiliki luas wilayah $34.127,17 \mathrm{~km}^{2}$ terdiri dari daratan seluas $21.951,71 \mathrm{~km}^{2}$ dan luas laut $11.962,42 \mathrm{~km}^{2}$, serta terdiri dari 52 pulau besar dan kecil dengan 13 kecamatan, 10 kelurahan, 100 kampung/desa. Jika ditinjau dari luas wilayah Kalimantan Timur, luas Kabupaten Berau adalah 13,92\% dari luas wilayah Kalimantan Timur, dengan prosentase luas perairan $28,74 \%$, dan jumlah penduduk pada tahun 2017 sebesar 220.601 jiwa, dengan jumlah penduduk laki-laki sebanyak 118.581 jiwa dan jumlah penduduk perempuan sebanyak 102.020 jiwa. Laju pertumbuhan penduduk Kabupaten Berau pada tahun 20162017 yaitu 0,03\%.

Kabupaten Berau merupakan salah satu daerah pintu gerbang pembangunan di wilayah Provinsi Kalimantan Timur bagian utara, yang terletak disebelah utara dari lbukota Provinsi Kalimantan Timur dan sekaligus merupakan wilayah daratan dan pesisir pantai yang memiliki sumber daya alam, dimana wilayah daratan terdiri dari gugusan bukit yang terdapat hampir disemua kecamatan terutama Kecamatan Kelay yang mempunyai perbukitan Batu Kapur yang luasnya hampir $100 \mathrm{~km}^{2}$. Sementara di daerah Kecamatan Tubaan terdapat perbukitan yang dikenal dengan Bukit Padai.

Daerah pesisir Kabupaten Berau terletak di Kecamatan Biduk-Biduk, Talisayan, Pulau Derawan dan Maratua yang secara geografis berbatasan langsung dengan lautan. Kecamatan Pulau Derawan terkenal sebagai daerah tujuan wisata yang memiliki pantai dan panorama yang sangat indah serta mempunyai beberapa gugusan pulau seperti Pulau Sangalaki, dengan batas wilayah sebelah utara berbatasan dengan Kabupaten Bulungan, sebelah timur berbatasan dengan Laut Sulawesi, sebelah selatan berbatasan dengan Kabupaten Kutai Timur serta sebelah barat berbatasan dengan Kabupaten Bulungan dan Kabupaten Kutai Kertanegara. Dalam pembagian wilayah pembangunan Kabupaten Berau memiliki 3 (tiga) wilayah yaitu:

1. Wilayah pantai yang meliputi Kecamatan Biduk-Biduk, Talisayan, Pulau Derawan, Maratua dan Tubaan.

2. Wilayah pedalaman yang meliputi Kecamatan Segah dan Kecamatan Kelay.

3. Wilayah kota yang meliputi Kecamatan Tanjung Redeb, Gunung Tabur, Sambaliung, Teluk Bayur.

Berada di daerah tropis dengan posisi geografis 10 LU-20 33 LS dan 1160 BT-1190 BT. Ketinggian Kabupaten Berau adalah di atas permukaan laut 5-55 m. Bentangan daratan Kabupaten Berau didominasi topografi dengan selang ketinggian $101 \mathrm{~m}-500 \mathrm{~m}$ $(37,1 \%)$, kemudian $23,2 \%$ merupakan bentang daratan dengan selang ketinggian 26-100 m, sisanya terbagi sebagai daerah dengan selang ketinggian 8-25 m (7,3\%) dan 0-7 m (12,2\%).

Kabupaten Berau dikenal sebagai salah satu destinasi pariwisata yang memiliki keragaman daya tarik wisata, khususnya wisata bahari. Data daya tarik wisata di Kabupaten Berau menurut kecamatan adalah sebagai berikut:

Tabel 2. Daya Tarik Wisata di Kabupaten Berau Menurut Kecamatan

\begin{tabular}{|l|l|l|}
\hline No. & \multicolumn{1}{|c|}{ Kecamatan } & \multicolumn{1}{|c|}{ Jumlah } \\
\hline 1 & Kelay & 22 \\
\hline 2 & Talisayan & 11 \\
\hline 3 & Tabalar & 7 \\
\hline 4 & Biduk-Biduk & 23 \\
\hline 5 & Pulau Derawan & 19 \\
\hline 6 & Maratua & 25 \\
\hline 7 & Sambaliung & 7 \\
\hline
\end{tabular}




\begin{tabular}{|l|l|l|}
\hline 8 & Tanjung Redeb & 14 \\
\hline 9 & Gunung Tabur & 7 \\
\hline 10 & Segah & 11 \\
\hline 11 & Teluk Bayur & 12 \\
\hline 12 & Batu Putih & 12 \\
\hline 13 & Biatan & 2 \\
\hline
\end{tabular}

Sumber: (Dinas Kebudayaan dan Pariwisata Kab. Berau, 2017)

Data di atas menunjukkan bahwa daya tarik wisata banyak terdapat di Kecamatan Maratua, Biduk-Biduk dan Kelay. Kecamatan Maratua dan Biduk-Biduk adalah kecamatan yang berada di Kepulauan Derawan yang merupakan daya tarik wisata utama di Kabupaten Berau.

Untuk mendukung sektor pariwisata di Kabupaten Berau, keberadaan layanan pendukung sangat dibutuhkan, seperti akomodasi dan restoran atau rumah makan. Data akomodasi di Kabupaten Berau dapat dilihat pada Tabel 3.

Tabel 3. Jumlah Akomodasi di Kabupaten Berau Menurut Kecamatan

\begin{tabular}{|l|l|c|c|c|}
\hline No. & \multicolumn{1}{|c|}{ Kec. } & $\begin{array}{c}\text { Hotel/ } \\
\text { Pengi- } \\
\text { napan }\end{array}$ & $\begin{array}{c}\text { Resort/ } \\
\text { Cottage }\end{array}$ & $\begin{array}{c}\text { Home- } \\
\text { stay }\end{array}$ \\
\hline 1 & Kelay & 4 & 0 & 0 \\
\hline 2 & Talisayan & 4 & 0 & 0 \\
\hline 3 & Tabalar & 0 & 0 & 0 \\
\hline 4 & $\begin{array}{l}\text { Biduk- } \\
\text { Biduk }\end{array}$ & 6 & 1 & 19 \\
\hline 5 & $\begin{array}{l}\text { Pulau } \\
\text { Derawan }\end{array}$ & 26 & 5 & 98 \\
\hline 6 & Maratua & 10 & 4 & 55 \\
\hline 7 & $\begin{array}{l}\text { Sambaliun } \\
\text { g }\end{array}$ & 2 & 0 & 0 \\
\hline 8 & $\begin{array}{l}\text { Tanjung } \\
\text { Redeb }\end{array}$ & 37 & 0 & 0 \\
\hline 9 & $\begin{array}{l}\text { Gunung } \\
\text { Tabur }\end{array}$ & 0 & 0 & 0 \\
\hline 10 & Segah & 3 & 0 & 0 \\
\hline 11 & $\begin{array}{l}\text { Teluk } \\
\text { Bayur }\end{array}$ & 3 & 0 & 0 \\
\hline 12 & Batu Putih & 2 & 0 & 0 \\
\hline 13 & Biatan & 4 & 0 & 0 \\
\hline Kab. Berau & $\mathbf{1 0 7}$ & $\mathbf{1 0}$ & $\mathbf{1 7 2}$ \\
\hline
\end{tabular}

Sumber: (Dinas Kebudayaan dan Pariwisata Kab. Berau, 2017)

Akomodasi di Kabupaten Berau banyak yang termasuk dalam jenis homestay sebanyak 172 dan kecamatan yang terdapat banyak homestay adalah Pulau Derawan. Keberadaan homestay di Pulau Derawan pada awalnya adalah untuk mendukung event Pekan Olahraga Nasional (PON) 2008 karena Pulau Derawan dipilih menjadi venue untuk pertandingan cabang olahraga bola voli pantai. Saat ini homestay menjadi pilihan bagi wisatawan yang berkunjung ke Pulau
Derawan. Akomodasi yang termasuk dalam jenis hotel banyak terdapat di Tanjung Redeb yang merupakan ibukota Kabupaten Berau.

Rerata lama menginap wisatawan yang berkunjung ke Kabupaten Berau adalah sebagai berikut:

Tabel 4. Rerata Lama Menginap Wisawatan di Kabupaten Berau

\begin{tabular}{|l|l|c|}
\hline No. & \multicolumn{1}{|c|}{ Wisatawan } & $\begin{array}{c}\text { Lama } \\
\text { Menginap }\end{array}$ \\
\hline 1 & $\begin{array}{l}\text { Wisatawan } \\
\text { nusantara }\end{array}$ & hari \\
\hline 2 & $\begin{array}{l}\text { Wisatawan } \\
\text { mancanegara }\end{array}$ & \\
\hline
\end{tabular}

Sumber: (Dinas Kebudayaan dan Pariwisata Kab. Berau, 2017)

Wisatawan nusantara memiliki rerata lama menginap selama 2 hari sedangkan wisatawan mancanegara 5 hari.

Jumlah restoran atau rumah makan di Kabupaten Berau mengalami peningkatan pada tahun 2016-2017. Data dapat dilihat pada Tabel 5.

Tabel 5. Jumlah Restoran atau Rumah Makan di Kabupaten Berau Menurut Kecamatan, 2016-2017

\begin{tabular}{|l|l|c|c|}
\hline No. & Kecamatan & $\mathbf{2 0 1 6}$ & $\mathbf{2 0 1 7}$ \\
\hline 1 & Kelay & 1 & 1 \\
\hline 2 & Talisayan & 1 & 1 \\
\hline 3 & Tabalar & 0 & 0 \\
\hline 4 & Biduk-Biduk & 0 & 0 \\
\hline 5 & $\begin{array}{l}\text { Pulau } \\
\text { Derawan }\end{array}$ & 5 & 5 \\
\hline 6 & Maratua & 2 & 2 \\
\hline 7 & Sambaliung & 3 & 3 \\
\hline 8 & $\begin{array}{l}\text { Tanjung } \\
\text { Redeb }\end{array}$ & 71 & 77 \\
\hline 9 & $\begin{array}{l}\text { Gunung } \\
\text { Tabur }\end{array}$ & 0 & 0 \\
\hline 10 & Segah & 0 & 0 \\
\hline 11 & Teluk Bayur & 2 & 2 \\
\hline 12 & Batu Putih & 0 & 0 \\
\hline 13 & Biatan & 0 & 0 \\
\hline Kab. Berau & $\mathbf{8 5}$ & $\mathbf{9 1}$ \\
\hline
\end{tabular}

Sumber: (Dinas Kebudayaan dan Pariwisata Kab. Berau, 2017)

Peningkatan jumlah restoran atau rumah makan terdapat di Kecamatan Tanjung Redeb yang mencapai $8,5 \%$.

Luas wilayah kecamatan yang ada di Kabupaten Berau relatif tidak merata. Hal ini dapat dilihat pada Grafik 1. 


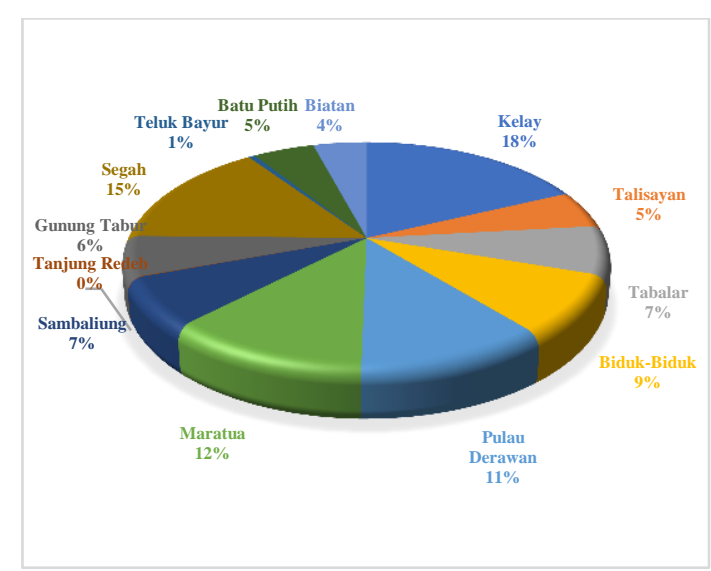

Grafik 1. Luas Wilayah Menurut Kecamatan di Kabupaten Berau

Sumber: (RPJMD 2016-2021 Kab. Berau)

Kecamatan dengan luas wilayah terkecil adalah Kecamatan Tanjung Redeb sebesar $0,07 \%$ dari total luas kabupaten. Sedangkan kecamatan dengan persentase luas terbesar adalah Kecamatan Kelay sebesar 17,98 \%. Hampir semua kecamatan tersebut dapat ditempuh dengan menggunakan transportasi darat, sedangkan satu kecamatan yaitu Kecamatan Maratua hanya bisa ditempuh dengan menggunakan transportasi air karena letaknya terpisah dengan pulau utama. Kecamatan dengan jarak terjauh dari ibukota kabupaten adalah Kecamatan Biduk-Biduk. Sedangkan kecamatan dengan jarak terdekat dengan ibu kota kabupaten adalah Kecamatan Tanjung Redeb yang sekaligus sebagai ibukota kabupaten.

Infrastruktur pendukung pariwisata di Kabupaten Berau antara lain adalah bandara, terminal, pelabuhan dan jalan. Bandara yang terdapat di Kabupaten Berau adalah Bandar Udara Kalimarau. Saat ini mempunyai panjang landasan $2.250 \times 45$ meter yang merupakan bandara pertama di Kalimantan Timur yang dilengkapi dengan centre light atau lampu yang berada di garis tengah landasan pacu. Bandar Udara Kalimarau merupakan yang kedua setelah Bandar Udara Soekarno-Hatta yang dilengkapi dengan centre light. Beberapa penerbangan yang sedang beroperasi adalah Garuda Indonesia, NAM Air, Sriwijaya Air, Wings Air, Susi Air dan Xpress Air. Kabupaten Berau memiliki terminal penumpang dan barang yaitu terminal regional tipe $\mathrm{B}$, terminal sekitar daerah pelabuhan, terminal sekitar Pasar Inpres, terminal Bandar Udara Kalimarau dan terminal sekitar Pasar Teluk Bayur. Untuk melayani transportasi laut, Kabupaten Berau memiliki Pelabuhan Tanjung Redeb. Pelabuhan Tanjung Redeb terletak pada Posisi 2-10-00 LU dan 117-29-00 BT dengan jarak dari muara laut masuk menyusuri sungai menuju Pelabuhan Tanjung Redeb 65 mil dan dilayari dengan kapal dengan waktu tempuh 6,5 jam. Infrastruktur jalan di Kabupaten Berau terdiri dari jalan kabupaten dan jalan provinsi. Jalan kabupaten adalah jalan tembus trans Kalimantan yaitu Tanjung Redeb-Tanjung. Selor dengan panjang 125 km, Tanjung Redeb-Talisayan panjang 161,1 $\mathrm{km}$, Talisayan-Sangkulirang 174,7 km, Tanjung Redeb-Sangkulirang 335,8 km. Untuk peningkatan jalan provinsi dilakukan pada Tanjung Redeb-Teluk Bayur $10 \mathrm{~km}$, Teluk Bayur-Labanan $23 \mathrm{~km}$ dan SambaliungTalisayan-Muara Lesan $10 \mathrm{~km}$.

Layanan pendukung pariwisata lainnya adalah keberadaan layanan di bidang perjalanan perjalanan wisata. Saat ini terdapat sekitar 12 usaha di bidang perjalanan di Kabupaten Berau.

Tabel 6. Daftar Usaha Bidang Perjalanan di Kabupaten Berau

\begin{tabular}{|c|l|l|}
\hline No. & \multicolumn{1}{|c|}{ Nama } & \multicolumn{1}{c|}{ Alamat } \\
\hline 1 & $\begin{array}{l}\text { Mahafi Travel } \\
\text { \& Centra } \\
\text { Loket }\end{array}$ & $\begin{array}{l}\text { Jl. Dr. Murjani III } \\
\text { No. 9 Tanjung } \\
\text { Redeb 77311 }\end{array}$ \\
\hline 2 & $\begin{array}{l}\text { PT Arta } \\
\text { Dinata Berau } \\
\text { Tour \& Travel } \\
\text { Service }\end{array}$ & $\begin{array}{l}\text { Jl. Bujangga } \\
\text { No.32 RT I Sei } \\
\text { Bedungun }\end{array}$ \\
\hline 3 & $\begin{array}{l}\text { PT Trans } \\
\text { Borneo Jaya }\end{array}$ & $\begin{array}{l}\text { Jl. Durian III } \\
\text { Tanjung Redeb }\end{array}$ \\
\hline 4 & $\begin{array}{l}\text { CV Makmur } \\
\text { Tour And } \\
\text { Travel }\end{array}$ & $\begin{array}{l}\text { Jl. Gatot Subroto } \\
\text { Tanjung Redeb }\end{array}$ \\
\hline 5 & $\begin{array}{l}\text { PT Alif } \\
\text { Anugrah Tour } \\
\text { and Travel }\end{array}$ & $\begin{array}{l}\text { Jl. Dr. Murjani II } \\
\text { Tanjung Redeb }\end{array}$ \\
\hline 6 & $\begin{array}{l}\text { PT Aero } \\
\text { Travel }\end{array}$ & $\begin{array}{l}\text { Jl. Dr. Murjani II } \\
\text { Tanjung Redeb }\end{array}$ \\
\hline 7 & $\begin{array}{l}\text { PT Panca } \\
\text { Mitra } \\
\text { Angkasa }\end{array}$ & $\begin{array}{l}\text { Jl. A. P. T. } \\
\text { Pranoto Tanjung } \\
\text { Redeb }\end{array}$ \\
\hline 8 & $\begin{array}{l}\text { PT Borneo } \\
\text { Wahan } \\
\text { Expres }\end{array}$ & $\begin{array}{l}\text { Jl. Pemuda No. } \\
47 \text { Tanjung } \\
\text { Redeb }\end{array}$ \\
\hline 9 & $\begin{array}{l}\text { PT Arimbi } \\
\text { Prapatan } \\
\text { Tour and } \\
\text { Travel }\end{array}$ & $\begin{array}{l}\text { Jl. Jenderal } \\
\text { Ahmad Yani } \\
\text { Tanjung Redeb }\end{array}$ \\
\hline 10 & $\begin{array}{l}\text { PT Tanjung } \\
\text { Harapan } \\
\text { Mulia (THM) } \\
\text { Tour and } \\
\text { Travel }\end{array}$ & $\begin{array}{l}\text { Jl. Niaga I } \\
\text { Tanjung Redeb }\end{array}$ \\
\hline 11 & $\begin{array}{l}\text { PT Lia Tours } \\
\text { and Travel }\end{array}$ & $\begin{array}{l}\text { Jl. Pangeran } \\
\text { Antasari Tanjung } \\
\text { Redeb }\end{array}$ \\
\hline 12 & PT Indo & J. S. A. Maulana \\
\hline
\end{tabular}




\begin{tabular}{|c|c|c|}
\hline No. & \multicolumn{1}{|c|}{ Nama } & Alamat \\
\hline & $\begin{array}{l}\text { Expres Tour } \\
\text { and Travel }\end{array}$ & Tanjung Redeb \\
\hline
\end{tabular}

Sumber: (Pemerintah Kabupaten Berau, 2018)

Pertumbuhan penyerapan tenaga kerja menurut lapangan usaha dari persentase tenaga kerja menurut mata pencaharian mengalami pergeseran yang cukup berarti, ini dapat dilihat pada Tabel 7.

Tabel 7. Persentase Penduduk di Kabupaten

Berau Menurut Mata Pencaharian, 2008-2011

\begin{tabular}{|c|l|r|r|r|r|}
\hline No & $\begin{array}{l}\text { Sektor/Sub } \\
\text { Sektor } \\
\text { Pekerjaan }\end{array}$ & $\mathbf{2 0 0 8}$ & $\mathbf{2 0 0 9}$ & $\mathbf{2 0 1 0}$ & $\mathbf{2 0 1 1}$ \\
\hline 1 & $\begin{array}{l}\text { Pertanian } \\
\text { (Pangan, } \\
\text { Perkebunan, } \\
\text { Perikanan, } \\
\text { Peternakan) }\end{array}$ & 37,64 & 44,50 & 38,74 & 35,91 \\
\hline 2 & Penggalian & 6,77 & 5,56 & 9.29 & 15,30 \\
\hline 3 & Industri & 4,11 & 4,11 & 2,25 & 3,06 \\
\hline 4 & $\begin{array}{l}\text { Listrik \& Air } \\
\text { Minum }\end{array}$ & 0,64 & 0,60 & 0,56 & 0,65 \\
\hline 5 & Bangunan & 7,29 & 6,43 & 6,57 & 5,03 \\
\hline 6 & $\begin{array}{l}\text { Perdagangan, } \\
\text { Hotel \& } \\
\text { Restoran }\end{array}$ & 16,64 & 15,57 & 16,40 & 17,10 \\
\hline 7 & $\begin{array}{l}\text { Angkutan \& } \\
\text { Komunikasi }\end{array}$ & 4,70 & 3,92 & 3,37 & 3,02 \\
\hline 8 & $\begin{array}{l}\text { Keuangan, } \\
\text { Persewaan \& } \\
\text { Jasa } \\
\text { Perusahaan }\end{array}$ & 1,22 & 0,17 & 2,73 & 1,91 \\
\hline 9 & $\begin{array}{l}\text { Jasa \& } \\
\text { Pemerintahan }\end{array}$ & 14,55 & 13,53 & 20,09 & 17,93 \\
\hline
\end{tabular}

Sumber: (BPS Kabupaten Berau, 2012)

Data yang disajikan sejak tahun 2008-2011 menunjukkan sektor pertanian pada tahun 2008 sebesar $37,64 \%$ dan pada tahun 2011 menjadi $35,91 \%$. Ini menunjukkan komposisi pekerja di sektor pertanian mengalami penurunan meskipun secara jumlah tenaga kerja mengalami peningkatan dari tahun ke tahun, berbanding terbalik dengan penurunan persentase sektor pertanian komposisi pekerja di sektor penggalian dan perdagangan, hotel dan restoran persentasenya mengalami peningkatan yang cukup signifikan. Hal ini menunjukkan dengan semakin meningkatnya pembangunan infrastruktur, sarana dan prasarana maka semakin besar lapangan usaha di luar sektor pertanian yang diminati oleh angkatan kerja sebagai lahan mata pencahariannya.

\subsubsection{Pembahasan}

Berdasarkan hasil penelitian menunjukkan bahwa kunjungan wisatawan ke Kabupaten Berau mengalami peningkatan. Hal ini diikuti dengan pengembangan layanan pendukung. $\mathrm{Hal}$ ini mendorong peningkatan jumlah tenaga kerja sektor pariwisata di Kabupaten Berau.
Data menunjukkan bahwa peningkatan yang terjadi cukup signifikan. Kepuasan wisatawan di semua layanan pendukung seperti hotel, restoran atau rumah makan dan sebagainya akan melengkapi pengalaman wisatawan yang berkunjung ke Kabupaten Berau. Hal ini didukung dengan kehandalan serta keramahtamahan pelaku pariwisata dalam memberikan layanan prima bagi wisatawan.

Dalam penelitian ini, pelaku pariwisata di Kabupaten Berau menjadi responden penelitian. Pelaku pariwisata yang menjadi responden terdiri dari masyarakat, industri maupun pemerintah. Responden sepakat bahwa hospitality terwujud dalam interaksi antara wisatawan dengan pelaku pariwisata, dan ini sejalan dengan Grönroos (2011) yang menyatakan bahwa pertemuan layanan (service encounter) dianggap oleh banyak orang sebagai peluang dan sarana, dimana industri akan mendekati pelanggan dan menyampaikan produk dan layanan yang dimiliki. Pelaku pariwisata bertanggung jawab untuk memberikan layanan melalui interaksi serta komunikasi. Hal ini menunjukkan pemahaman yang cukup jelas tentang implikasi konsep hospitality bagi industri pariwisata.

Selain itu, para responden percaya bahwa perhatian yang adil dan setara untuk semua wisatawan dapat dijamin jika pelaku pariwisata berperilaku secara profesional dan sesuai dengan budaya dan nilai-nilai organisasi (Crotts, Dickson, \& Ford, 2005). Responden menekankan aspek-aspek seperti efisiensi, kecepatan dan ketepatan waktu, namun pada praktiknya masih terdapat pelaku pariwisata yang tidak menerapkannya bahkan terdapat kecenderungan meremehkan nilai-nilai perilaku yang ramah, seperti menyambut tamu dengan kehangatan. Lashley (2000) berpendapat, keterampilan yang baik dalam cara melayani pelanggan akan memungkinkan untuk menjadi "tuan rumah yang baik" namun tidak menjamin perilaku yang ramah dari tuan rumah (host). Oleh karena itu, penekanan pada standar tinggi dan profesionalisme sebagai fokus utama dalam penyampaian produk dan layanan. Apabila hal ini tidak menjadi perhatian maka dapat menciptakan "kecenderungan destruktif" untuk industri pariwisata khususnya dalam standarisasi pelayanan dan dalam perspektif jangka panjang (Ritzer, 2007), pelaku pariwisata akan mengabaikan pentingnya keramahtamahaan dan hubungan antara tuan rumah dengan tamu.

Hasil penelitian, khususnya di sektor industri seperti hotel, menunjukkan bahwa jabatan karyawan di suatu hotel akan 
cenderung termotivasi oleh niat yang berbeda dalam memenuhi harapan tamu. Untuk karyawan yang berada di tingkat manajerial, telah mampu memahami pentingnya konsep memenuhi bahkan melebihi harapan tamu dalam sebuah bisnis hotel, hal ini merupakan bagian dari konsep hospitality. Untuk memastikan "semangat keramahtamahan", beberapa karyawan hotel menganggap diri mereka sebagai tuan rumah, dan hubungan dengan para tamu adalah sama serta didasarkan pada rasa saling menghormati. Meskipun demikian, terlepas dari bagaimana karyawan memposisikan diri dengan menghormati tamu, responden mengakui bahwa lingkungan hotel mewajibkan karyawan untuk berperilaku secara profesional dan membatasi karyawan dalam ekspresi emosi negatif.

Emosi pelaku pariwisata mengacu pada pekerjaan yang dilakukan terkait dengan layanan yang melampaui tanggung jawabnya, seperti tersenyum, bertindak bahagia dan sejenisnya (Johanson \& Woods, 2008). Responden mengakui bahwa emosi memainkan peran penting dalam industri pariwisata, karena memerlukan tampilan emosi tertentu, yang belum tentu benar-benar dirasakan dan bahkan dapat bertentangan dengan perasaan batin (Mann, 1999). Responden mengakui bahwa terdapat tuntutan untuk menutupi emosi negatif dengan tersenyum dan menunjukkan wajah layanan yang sebenarnya. Bagi masyarakat, hal ini merupakan tantangan. Masih ditemukan pada kelompok masyarakat yang belum mampu melakukan. Ini dikarenakan masyarakat tidak mendapatkan 'pendidikan' terkait hospitality sehingga tidak mengetahui bagaimana penerapannya. Lembaga pemerintah harus memainkan peran yang lebih kuat dalam pengembangan kompetensi (Kristiana \& Nathalia, 2017). Sedangkan bagi karyawan di sektor industri pariwisata walaupun memiliki latar belakang pendidikan di bidang pariwisata maupun telah mendapatkan sosialiasi dari perusahaan, namun masih terlihat belum optimal.

Hasil dari studi menunjukkan bahwa pemahaman pelaku pariwisata di Kabupaten Berau tentang hospitality belum menyeluruh. Para pelaku pariwisata lebih memahami konsep layanan daripada hospitality. Mayoritas pelaku pariwisata tidak dapat secara akurat menggambarkan hospitality atau membedakannya dari layanan. Hanya sedikit dari pelaku pariwisata yang mampu mendefinisikan dan menggambarkan konsep hospitality, namun ini pun masih mengacu pada istilah dan konsep manajemen layanan. Sebagian besar pelaku pariwisata berjuang untuk memahami atau mengungkapkan pemahaman dan persepsi tentang hospitality. Praktik yang konsisten dalam menjalankan konsep hospitality dapat memengaruhi perilaku dari pelaku pariwisata.

\subsection{Simpulan dan Saran}

\subsubsection{Simpulan}

Hasil dari studi menunjukkan bahwa pemahaman pelaku pariwisata di Kabupaten Berau tentang hospitality belum menyeluruh. Para pelaku pariwisata lebih memahami konsep layanan daripada hospitality. Mayoritas pelaku pariwisata tidak dapat secara akurat menggambarkan hospitality atau membedakannya dari layanan. Hanya sedikit dari pelaku pariwisata yang mampu mendefinisikan dan menggambarkan konsep hospitality, namun ini pun masih mengacu pada istilah dan konsep manajemen layanan. Sebagian besar pelaku pariwisata berjuang untuk memahami atau mengungkapkan pemahaman dan persepsi tentang hospitality. Praktik yang konsisten dalam menjalankan konsep hospitality dapat memengaruhi perilaku dari pelaku pariwisata.

\subsubsection{Saran}

Saran yang diberikan penulis kepada pelaku pariwisata untuk sektor industri adalah mengembangkan program pelatihan secara berkelanjutan untuk meningkatkan pemahaman karyawan tentang hospitality. Selain itu perlu dikembangkan program pengembangan diri bagi seluruh karyawan sehingga karyawan dapat memberikan kualitas layanan yang optimal. Manajemen juga terus mengembangkan budaya organisasi yang selaras dengan konsep hospitality.

Saran bagi pemerintah adalah mengembangkan program sosialiasi dan penyuluhan tentang konsep hospitality bagi masyarakat sehingga masyarkat memiliki perilaku yang merepresentasikan konsep hospitality. Pemerintah juga harus melakukan pendampingan secara berkelanjutan.

Untuk keberlanjutan penelitian dapat dilakukan dengan mengembangkan penelitian ini melalui penambahan jumlah responden yang terlibat dalam penelitian selanjutnya dengan lokus penelitian yang berbeda. 


\section{Daftar Pustaka}

[1] Cook, R. A., Hsu, C. H. C., \& Taylor, L. L. (2018). Tourism: The Business of Hospitality and Travel, 6th Edition. Edinburgh Gate Harlow: Pearson.

[2] Cooper, C., Fletcher, J., Fyall, A., Gilbert, D., \& Wanhill, S. (2008). Tourism: Principles and Practice. New Jersey: Financial Times/Prentice Hall.

[3] Crotts, J. C., Dickson, D. R., \& Ford, R. C. (2005). Aligning organizational processes with mission: The case of service excellence. Academy of Management Perspectives, 19(3), 54-68. https://doi.org/10.5465/ame.2005.1873321 5

[4] Gazali, M. (2017). Penguatan Ekonomi Masyarakat Kabupaten Berau Bidang Industri Pariwisata Tahun 2018.

[5] Grönroos, C. (2011). Value co-creation in service logic: A critical analysis. Marketing Theory, 11(3), 279-301. https://doi.org/10.1177/147059311140817 7

[6] Holloway, C., \& Taylor, N. (2006). The Business of Tourism (7th ed.). New Jersey: Pearson.

[7] Johanson, M. M., \& Woods, R. H. (2008). Recognizing the emotional element in service excellence. Cornell Hospitality Quarterly, 49(3), 310-316. https://doi.org/10.1177/193896550831626 7

[8] Kandampully, J., \& Solnet, D. (2015). Service Management Principles for Hospitality and Tourism (2nd ed.). Des Moines, IA: Kendall Hunt.

[9] Kementerian Pariwisata Republik Indonesia. (2017). Laporan Akuntabilitas Kinerja Kementerian Pariwisata Tahun 2017. Jakarta.

[10] Kernbach, S., \& Schutte, N. S. (2005). The impact of service provider emotional intelligence on customer satisfaction. Journal of Services Marketing, 19(7), 438444.

https://doi.org/10.1108/088760405106259 45

[11] Kotler, P., \& Keller, K. L. (2015). Marketing Management. Prentice Hall (15th ed.). New Jersey: Pearson. https://doi.org/10.1177/106002801453419 5

[12] Kristiana, Y., \& Nathalia, T. C. (2017). Tourism Stakeholders: Towards Sustainable Tourism Development. In 15th APacCHRIE Conference. Denpasar: International Bali Institute of Tourism.

[13] Langhorn, S. (2004). How emotional intelligence can improve management performance. International Journal of Contemporary Hospitality Management, 16(4), 220-230. https://doi.org/10.1108/095961104105373 79

[14] Lashley, C. (2000). Towards A Theoretical Understanding, in Lashley, C. and Morrison, A. (Eds). In Search of Hospitality: Theoretical Perspectives and Debates (pp. 1-17). Oxford: ButterworthHeinemann.

[15] Lashley, C. (2007). Discovering hospitality: observations from recent research. International Journal of Culture, Tourism and Hospitality Research, 1(3), 214-226. https://doi.org/10.1108/175061807108177 47

[16]Mann, S. (1999). Emotion at Work: To What Extent are We Expressing, Suppressing, or Faking It? European Journal of Work and Organizational Psychology, 8(3), 347-369. https://doi.org/10.1080/135943299398221

[17] Meyer, D. (2008). Setting the Table: The Transforming Power of Hospitality in Business. New York: HarperCollins Publishers.

[18]Moleong, L. J. (2010). Metodologi Penelitian Kualitatif. Bandung: PT Remaja Rosdakarya.

[19] Pezzotti, G. (2011). The Essence of Hospitality and Service, in Sturman, M.C., Corgel, J.B. and Verma, R. (Eds). In The Cornell School of Hotel Administration on Hospitality: Cutting Edge Thinking and Practice (pp. 5-18). New Jersey: John Wiley \& Sons.

[20] Pizam, A. (2005). International Encyclopedia of Hospitality Management. Butterworth-Heinemann: Elsevier Oxford.

[21]Popova, D. (2012). Hospitality Management (Lecture notes).

[22] Ritzer, G. (2007). Inhospitable hospitality?, in Lynch, P., Morrison, A. and Lashley, C. (Eds). In Hospitality: A Social Lens (pp. 129-139). Amsterdam: Elsevier.

[23] Sugiyono. (2016). Metode Penelitian Kuantitatif, Kualitatif dan R\&D. Bandung: Alfabeta.

[24] Teng, C. C. (2011). Commercial hospitality in restaurants and tourist accommodation: Perspectives from international consumer experience in Scotland. International Journal of Hospitality Management, 30(4), 866-874.

https://doi.org/10.1016/j.ijhm.2011.01.007

[25] Varca, P. E. (2004). Service skills for 
service workers: Emotional intelligence and beyond. Managing Service Quality: An International Journal, 14(6), 457-467. https://doi.org/10.1108/096045204105697 93

[26]Winsted, K. F. (2000). Service behaviors that lead to satisfied customers. European Journal of Marketing, 34(3/4), 399-417. https://doi.org/10.1108/030905600103119 20 